\section{Kidney \\ Blood Pressure Research}

Review

\title{
Phosphate Homeostasis, Inflammation and the Regulation of FGF-23
}

\author{
Florian Lang ${ }^{\mathrm{a}}$ Christina Leibrock ${ }^{\mathrm{b}} \quad$ Aleksandra A. Pandyrac ${ }^{\mathrm{c}}$ Christos Stournaras ${ }^{\mathrm{d}}$ \\ Carsten A. Wagner Michael Föller $^{f}$

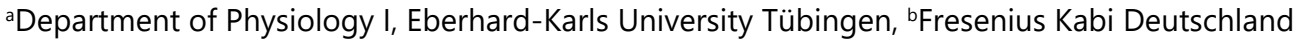 \\ $\mathrm{GmbH}$, Bad Homburg, 'Department of Molecular Medicine II, Heinrich Heine University Duesseldorf, \\ Duesseldorf, Germany, dDepartment of Biochemistry, University of Crete Medical School, Heraklion, \\ Greece, eInstitute of Physiology, NCCR Kidney.CH, University of Zürich, Zürich, Switzerland, fUniversity \\ of Hohenheim, Institute of Physiology, Stuttgart, Germany
}

\section{Key Words}

$1,25(\mathrm{OH})_{2} \mathrm{D}_{3} \cdot$ Orai1 $\bullet$ iron deficiency $\bullet \mathrm{TNF} \alpha \cdot \mathrm{TGF} \beta 2$

\begin{abstract}
Fibroblast growth factor 23 (FGF23) is released primarily from osteoblasts/osteocytes in bone. In cooperation with the transmembrane protein Klotho, FGF23 is a powerful inhibitor of $1 \alpha$ $25 \mathrm{OH}$ Vitamin D Hydroxylase (Cyp27b1) and thus of the formation of 1,25-dihydroxyvitamin $\mathrm{D}_{3}\left(1,25(\mathrm{OH})_{2} \mathrm{D}_{3}\right)$. As $1,25(\mathrm{OH})_{2} \mathrm{D}_{3}$ up-regulates intestinal calcium and phosphate absorption, the downregulation of $1,25(\mathrm{OH})_{2} \mathrm{D}_{3}$ synthesis counteracts phosphate excess and tissue calcification. FGF23 also directly inhibits renal phosphate reabsorption. Other actions of FGF23 include triggering of cardiac hypertrophy. FGF23 formation and/or release are stimulated by $1,25(\mathrm{OH})_{2} \mathrm{D}_{3^{\prime}}$ phosphate excess, $\mathrm{Ca}^{2+}$, PTH, leptin, catecholamines, mineralocorticoids, volume depletion, lithium, high fat diet, iron deficiency, TNF $\alpha$ and TGFß2. The stimulating effect of $1,25(\mathrm{OH})_{2} \mathrm{D}_{3}$ on FGF23 expression is dependent on RAC1/PAK1 induced actin-polymerisation. Intracellular signaling involved in the stimulation of FGF23 release also includes increases in the cytosolic $\mathrm{Ca}^{2+}$ concentration ([Ca $\left.\left.{ }^{2+}\right] \mathrm{i}\right)$ following intracellular $\mathrm{Ca}^{2+}$ release and store-operated $\mathrm{Ca}^{2+}$ entry (SOCE). SOCE is accomplished by the $\mathrm{Ca}^{2+}$ release-activated calcium channel protein 1 (Orai1) and its stimulator stromal interaction molecule 1 (STIM1). Expression of Orai1, SOCE and FGF23formation are up-regulated by the proinflammatory transcription factor NFkB. The present brief review describes the cellular mechanisms involved in FGF23 regulation and its sensitivity to both phosphate metabolism and inflammation. The case is made that up-regulation of FGF23 by inflammatory mediators and signaling may amplify inflammation by inhibiting formation of the anti-inflammatory $1,25(\mathrm{OH})_{2} \mathrm{D}_{3}$.




\section{Kidney Blood Pressure Research}

Kidney Blood Press Res 2018;43:1742-1748

\begin{tabular}{l|l}
\hline DOI: 10.1159/000495393 & (c) 2018 The Author(s). Published by S. Karger AG, Base
\end{tabular}

Published online: 23 November 2018 www.karger.com/kbr

Lang et al.: Regulation of FGF23 Release

\section{Introduction}

Fibroblast growth factor 23 (FGF23) is primarily released from bone [1], to a lesser extent from the spleen and brain [1], and, under pathophysiological conditions, from other organs, including kidney [2]. FGF23 adjusts the regulation of calcium and phosphate metabolism to the mineralization of bone [1]. FGF23 down-regulates renal $1 \alpha 250 \mathrm{H}$ vitamin D hydroxylase (Cyp27b1) and thus curtails the formation of 1,25-dihydroxyvitamin $\mathrm{D}_{3}\left(1,25(\mathrm{OH})_{2} \mathrm{D}_{3}\right)$ [1]. Moreover, FGF23 accelerates $1,25(\mathrm{OH})_{2} \mathrm{D}_{3}$ degradation by the up-regulation of 25-hydroxyvitamin D 24-hydroxylase (Cyp24) [1]. As 1,25(OH) ${ }_{2} \mathrm{D}_{3}$ is a powerful stimulator of intestinal absorption and renal reabsorption of calcium and phosphate, the downregulation of $1,25(\mathrm{OH})_{2} \mathrm{D}_{3}$ by FGF23 decreases plasma calcium and phosphate concentrations [1]. Furthermore, FGF23 directly inhibits the renal phosphate reabsorption and thus enhances renal phosphate excretion [1]. FGF23 thus limits intestinal phosphate uptake and increases renal phosphate elimination when bone mineralization is abundant [1]. FGF23 release is further stimulated by $1,25(\mathrm{OH})_{2} \mathrm{D}_{3}$ or activation of the vitamin $\mathrm{D}$ receptor (VDR), a negative feedback loop contributing to the limitation of $1,25(\mathrm{OH})_{2} \mathrm{D}_{3}$ formation [1].

The effect of FGF23 on renal $1,25(\mathrm{OH})_{2} \mathrm{D}_{3}$ formation requires the cooperation with the co-receptor Klotho [1]. $1,25(\mathrm{OH})_{2} \mathrm{D}_{3}$, calcium and phosphate plasma levels are excessive in mice deficient in either FGF23 or Klotho leading to severe tissue calcification $[1,3,4]$, and a variety of disorders including deranged bone mineralization, growth deficit, cardiac hypertrophy, emphysema, hypogonadism, infertility, hearing loss, cognitive impairment, decreased physical performance, thymus atrophy, reduced fat tissue and sarcopenia $[1,2]$. As a result, life span is dramatically decreased in FGF23- or Klotho-deficient animals [1]. The tissue calcification is not simply due to calcium phosphate super-saturation, but results from the triggering of osteogenic/chondrogenic trans-differentiation of affected cells [5]. In Klotho-deficient mice, the excessive formation of $1,25(\mathrm{OH})_{2} \mathrm{D}_{3}$ is followed by dramatic increases in FGF23 release and plasma levels [1].

Parathyroid hormone (PTH) is another powerful stimulator of FGF23 synthesis and release. PTH acts in bone via the orphan nuclear receptor Nurr1 to enhance FGF23 transcription. Thereby, PTH enhances renal phosphate excretion directly and indirectly via FGF23. FGF23, in turn, suppresses PTH secretion in a Klotho-dependent manner, a mechanism defective in patients with chronic kidney disease with reduced levels of Klotho.

The present brief review discusses cellular mechanisms involved in the regulation of FGF23 formation/release and its involvement in inflammatory disease.

\section{Stimulators of FGF23 release}

In addition to excess of phosphate and $1,25(\mathrm{OH})_{2} \mathrm{D}_{3}$, enhanced extracellular $\mathrm{Ca}^{2+}$ concentrations, parathyroid hormone (PTH), leptin, catecholamines, mineralocorticoids, volume depletion, lithium, inflammation, iron deficiency, high fat diet, TNF $\alpha$ and TGFß2 stimulate FGF23 release from bone [1, 6-13]. The increase of FGF23 plasma levels following high-fat diet is at least partially due to upregulation of TNF $\alpha$ [12].

In chronic kidney disease (CKD), FGF23 plasma levels are typically elevated prior to development of hyperphosphatemia and hyperparathyroidism [1, 14]. Common complications of CKD include inflammation and iron deficiency, both stimulators of FGF23 production in bone [11]. In contrast to Klotho-deficient mice, $1,25(\mathrm{OH})_{2} \mathrm{D}_{3}$ plasma levels are decreased in CKD $[2,15]$. Thus, $1,25(\mathrm{OH})_{2} \mathrm{D}_{3}$ cannot account for the excessive FGF23 plasma levels in CKD. Treatment of uremic rats with neutralizing anti-FGF23 antibodies restores $1,25(\mathrm{OH})_{2} \mathrm{D}_{3}$ plasma levels, but aggravates hyperphosphatemia and increases mortality [14]. FGF23 plasma concentrations are further enhanced in polycystic kidney disease [16], diabetic nephropathy [17], shiga toxin- induced hemolytic uremic syndrome [18] and nephrotic syndrome [19]. 


\section{Kidney Blood Pressure Research}

Kidney Blood Press Res 2018;43:1742-1748

\begin{tabular}{l|l}
\hline DOI: 10.1159/000495393 & (C) 2018 The Author(s). Published by S. Karger AG, Base
\end{tabular} Published onlıne: 23 November 2018 www.karger.com/kbr

\section{Cellular mechanisms regulating FGF23 release}

FGF23 formation and release are inhibited by the phosphate-regulating gene with homology to endopeptidase (PHEX) and dentin matrix protein or cyclin D binding myblike protein 1 (DMP-1) [1]. Loss of function mutations of PHEX or DMP-1 lead to dramatic increases in FGF23 release from bone with increased circulating levels of FGF23 [20, 21]) impaired $1,25(\mathrm{OH})_{2} \mathrm{D}_{3}$ formation, renal phosphate wasting, hypophosphatemia, and impairment of bone mineralization [21-24], as amplified below.

The stimulating effect of $1,25(\mathrm{OH})_{2} \mathrm{D}_{3}$ on FGF23 expression requires polymerized actin filaments which are regulated by the pro-inflammatory transcription factor nuclear factor kappa-light-chain-enhancer of activated B cells (NF-kB), ras-related C3 botulinum toxin substrate 1 (Rac1) and p21 protein-activated kinase 1 (PAK1) [25].

NFKB stimulates the expression of Orai1, a Ca ${ }^{2+}$ channel activated by the $\mathrm{Ca}^{2+}$ sensor STIM1 following $\mathrm{Ca}^{2+}$ depletion of intracellular $\mathrm{Ca}^{2+}$ stores [26]. Orai1/STIM1 thus affect store-operated $\mathrm{Ca}^{2+}$ entry (SOCE) [26]. Osteoblasts express Orai1, and SOCE in those cells is disrupted by pharmacological inhibition of either NFKB or Orai1 [26]. Stimulation of SOCE enhances FGF23 expression, an effect mimicked by the $\mathrm{Ca}^{2+}$ ionophore ionomycin [26]. Conversely, FGF23 expression is suppressed by pharmacologic or siRNA-mediated knockout of Orai1, as well as pharmacologic inhibition of NFKB [26]. Thus, FGF23 formation is up-regulated by $\mathrm{Ca}^{2+}$ entry through NFKB-dependent Orai1 [26]. As phosphate-induced osteogenic/chondrogenic transdifferentiation involves TGFß and NFKB [27, 28], it is tempting to speculate that TGFß, NFкB-activity, Orai1 expression and SOCE contribute to the phosphate-induced stimulation of FGF23 formation. However, further experiments are required to fully elucidate the role of this signaling pathway in the stimulation of FGF23 by phosphate.

NFKB-activity, Orai1 expression and SOCE are upregulated by aldosterone-inducible serum \& glucocorticoid inducible kinase SGK1 [29]. Aldosterone up-regulates SOCE and FGF23 formation in osteoblasts. The effect of aldosterone on FGF23 expression is abrogated by blockage of the mineralocorticoid receptor and by pharmacological inhibition of SGK1, NFKB, and Orai1 [30]. FGF23 plasma concentration in mice increases following administration of the mineralocorticoid DOCA or by salt depletion [30]. Renal salt loss and extracellular volume depletion probably account for the enhanced FGF23 plasma levels in mice lacking functional thiazide-sensitive $\mathrm{NaCl}$ transporter NCC [10], mice which express the inactive Ste20-Related Proline/Alanine-Rich Kinase (SPAK) [31] or mice expressing the inactive oxidative stress-responsive kinase (OSR) [32]. It is unclear whether enhanced FGF23 levels in annexin 7- deficient mice [33] are due to volume depletion or inflammation.

NFkB-activity, Orai1 expression and SOCE are further up-regulated by treatment of osteoblasts with lithium [34]. Lithium-treatment enhances FGF23 plasma concentrations in both mice [35] and humans [36]. The effect of lithium on FGF23 in osteoblasts is disrupted by pharmacological inhibition of Orai1 und NFKB. Lithium thus stimulates FGF23 expression/ release at least in part by stimulating $\mathrm{NF \kappa B}$ with subsequent up-regulation of Orai1 and SOCE [34].

Orai1 expression and SOCE are downregulated by the energy sensing AMP-activated kinase (AMPK) [37, 38]. Accordingly, FGF23 gene transcription is enhanced in AMPK $\alpha 1-$ knockout mice [39]. FGF23 gene transcription in UMR106 osteoblast-like cells is decreased by the AMPK activator, 5-aminoimidazole-4-carboxamide ribonucleotide (AICAR) and increased by the AMPK inhibitor, dorsomorphin dihydrochloride (compound C) [39].

The up-regulation of FGF23 by inflammation and iron-deficiency involves activation of hypoxia-inducible factor (HIF)-1 $\alpha$ [40].

CO-releasing molecule (CORM-2) stimulates FGF23 release in vivo and in vitro [41] thus decreasing the formation of $1,25(\mathrm{OH})_{2} \mathrm{D}_{3}[41]$. 


\section{Kidney Blood Pressure Research}

\section{FGF23 cleavage}

FGF23 plasma levels are a function not only of FGF23 formation/release, but as well of FGF23 cleavage [13]. FGF23 cleavage is stimulated by iron deficiency [40] and the enhanced formation of FGF23 in iron deficiency is thus paralleled by enhanced FGF23 cleavage [40]. In autosomal dominant hypophosphatemic rickets (ADHR) gain-of-function mutations in FGF23 prevent the proteolytic FGF23 cleavage leading to phosphate wasting [13]. The extent depends on the rate of FGF23 formation which is enhanced by iron deficiency [13].

\section{Clinical significance of FGF23 excess}

The excessive increase of plasma FGF23 concentrations, compromized $1,25(\mathrm{OH})_{2} \mathrm{D}_{3}$ formation and renal phosphate wasting in patients carrying loss of function mutations of PHEX $[20,22])$ interferes with bone mineralization leading to several clinical disorders including limb deformity, short stature, arthritis, enthesopathy, hearing impairment, optic atrophy and nephrocalcinosis [21-24]. Loss of function mutations of DMP-1 lead to rickets/ osteomalacia later during childhood or in adulthood [23].

The FGF23 excess in Klotho deficient mice is paralleled by pathological cardiac remodeling with left ventricular hypertrophy and myocardial fibrosis [42], activated cardiac Fgf23/Fgf receptor (Fgfr) 4/calcineurin/nuclear factor of activated T cell (NFAT) signaling, induction of pro-hypertrophic NFAT target genes including Rcan1, bMHC, brain natriuretic peptide $(B N P)$, and atrial natriuretic peptide $(A N P)$, activated cardiac ERK1/2 and enhanced expression of Tgf- $\beta 1$, collagen I, and Mmp2 [42]. Those effects are not observed in other mice with excessive FGF23 and may require hyperphosphatemia and hypercalcemia [42].

\section{FGF23 in the regulation of inflammation}

The sensitivity of FGF23 formation to TGFß2, TNF $\alpha$ and the pro-inflammatory transcription factor NFKB links FGF23 release and $1,25(\mathrm{OH})_{2} \mathrm{D}_{3}$-formation to inflammation (Fig. 1). As a matter of fact, the effects of $1,25(\mathrm{OH})_{2} \mathrm{D}_{3}$ are not limited to regulation of mineral metabolism but affect a variety of functions including inhibition of inflammation [43-46]. It is tempting to speculate that the stimulation of FGF23 by inflammation functions as an amplifyer, as it suppresses the formation of the anti-inflammatory $1,25(\mathrm{OH})_{2} \mathrm{D}_{3}$. Along those lines, the enhanced release of FGF23 during inflammation [47] and mineralocorticoid excess could explain the enigmatic association between enhanced FGF23 plasma levels and the unfavorable course of several diseases including CKD [2].

Clearly, additional investigations are warranted to elucidate the impact of the FGF23/1,25(OH) $)_{2}$ axis on inflammatory disease.

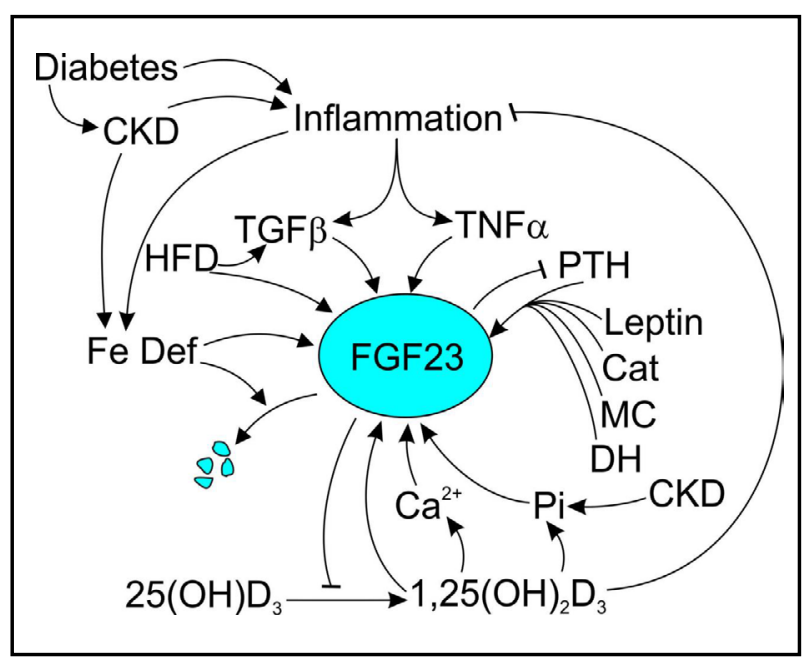

Fig. 1. Regulation of FGF23 and its impact on inflammation. Abbreviations: Cat $=$ catecholamines, $\mathrm{CKD}=$ chronic kidney disease, $\mathrm{DH}=$ dehydration, Fe Def = iron deficiency, HFD = high fat diet, $\mathrm{MC}=$ mineralocorticoids, $\mathrm{Pi}=$ phosphate. 


\section{Kidney \\ Blood Pressure Research}

Lang et al.: Regulation of FGF23 Release

\section{Conclusion}

Stimulators of FGF23 formation and release include $1,25(\mathrm{OH})_{2} \mathrm{D}_{3}$, phosphate excess, $\mathrm{Ca}^{2+}, \mathrm{PTH}$, leptin, catecholamines, mineralocorticoids, volume depletion, lithium, high fat diet, iron deficiency, TNF $\alpha$ and TGFß2. Signaling involved in the stimulation of FGF23 formation includes RAC1/PAK1 dependent actin-polymerisation and up-regulation of the transcription factor $\mathrm{NFKB}$ followed by increased expression of $\mathrm{Ca}^{2+}$ channel protein Orai1 and its stimulator STIM, which accomplish store operated $\mathrm{Ca}^{2+}$ entry (SOCE). The sensitivity of FGF23 formation to TNF $\alpha$, TGFß2 and the proinflammatory transcription factor NFKB establishes a link between mineral metabolism and inflammation.

\section{Acknowledgements}

Work in the laboratories of the authors has been supported by the Deutsche Forschungsgemeinschaft (MF, FL) and the Swiss National Science Foundation (CAW). Their support is gratefully acknowledged.

\section{Disclosure Statement}

The authors declare they have no conflict of interest.

\section{References}

1 Hu MC, Shiizaki K, Kuro O, Moe OW: Fibroblast growth factor 23 and klotho: physiology and pathophysiology of an endocrine network of mineral metabolism. Annu Rev Physiol 2013;75:503-533.

-2 Lang F, Foller M: Enigmatic Cassandra: renal FGF23 formation in polycystic kidney disease. Kidney Int 2014;85:1260-1262.

-3 Leibrock CB, Alesutan I, Voelkl J, Michael D, Castor T, Kohlhofer U, Quintanilla-Martinez L, Kubler L, Mannheim JG, Pichler BJ, Rosenblatt KP, Kuro-o M, Lang F: Acetazolamide sensitive tissue calcification and aging of klotho-hypomorphic mice. J Mol Med (Berl) 2016;94:95-106.

-4 Leibrock CB, Feger M, Voelkl J, Kohlhofer U, Quintanilla-Martinez L, Kuro-o M, Lang F: Partial Reversal of Tissue Calcification and Extension of Life Span following Ammonium Nitrate Treatment of Klotho-Deficient Mice. Kidney Blood Press Res 2016;41:99-107.

-5 Voelkl J, Alesutan I, Leibrock CB, Quintanilla-Martinez L, Kuhn V, Feger M, Mia S, Ahmed MS, Rosenblatt KP, Kuro OM, Lang F: Spironolactone ameliorates PIT1-dependent vascular osteoinduction in klothohypomorphic mice. J Clin Invest 2013;123:812-822.

-6 Pi M, Quarles LD: Novel bone endocrine networks integrating mineral and energy metabolism. Curr Osteoporos Rep 2013;11:391-399.

7 Fajol A, Chen H, Umbach AT, Quarles LD, Lang F, Foller M: Enhanced FGF23 production in mice expressing PI3K-insensitive GSK3 is normalized by beta-blocker treatment. FASEB J 2016;30:994-1001.

8 Lang F, Völkl J: Zelluläre Mechanismen in der Regulation von FGF23. connexi 2017;3:8-11.

-9 Feger M, Hase P, Zhang B, Hirche F, Glosse P, Lang F, Foller M: The production of fibroblast growth factor 23 is controlled by TGF-beta2. Sci Rep 2017;7:4982.

10 Pathare G, Anderegg M, Albano G, Lang F, Fuster DG: Elevated FGF23 Levels in Mice Lacking the ThiazideSensitive NaCl cotransporter (NCC). Sci Rep 2018;8:3590.

11 Francis C, David V: Inflammation regulates fibroblast growth factor 23 production. Curr Opin Nephrol Hypertens 2016;25:325-332.

12 Glosse P, Fajol A, Hirche F, Feger M, Voelkl J, Lang F, Stangl GI, Foller M: A high-fat diet stimulates fibroblast growth factor 23 formation in mice through TNFalpha upregulation. Nutr Diabetes 2018;8:36. 


\section{Kidney \\ Blood Pressure Research}

13 Wolf M, White KE: Coupling fibroblast growth factor 23 production and cleavage: iron deficiency, rickets, and kidney disease. Curr Opin Nephrol Hypertens 2014;23:411-419.

14 Hasegawa H, Nagano N, Urakawa I, Yamazaki Y, Iijima K, Fujita T, Yamashita T, Fukumoto S, Shimada T: Direct evidence for a causative role of FGF23 in the abnormal renal phosphate handling and vitamin D metabolism in rats with early-stage chronic kidney disease. Kidney Int 2010;78:975-980.

15 Juppner H: Phosphate and FGF-23. Kidney Int 2011;79121:S24-27.

-16 Spichtig D, Zhang H, Mohebbi N, Pavik I, Petzold K, Stange G, Saleh L, Edenhofer I, Segerer S, Biber J, Jaeger P, Serra AL, Wagne CA: Renal Expression of FGF23 and Peripheral Resistance to 1 elevated FGF23 in 2 Rodent Models of Polycystic Kidney Disease. Kidney Int 2014;85:1340-1350.

17 Zanchi C, Locatelli M, Benigni A, Corna D, Tomasoni S, Rottoli D, Gaspari F, Remuzzi G, Zoja C: Renal expression of FGF23 in progressive renal disease of diabetes and the effect of ace inhibitor. PLoS One 2013;8:e70775.

18 Feger M, Mia S, Pakladok T, Nicolay JP, Alesutan I, Schneider SW, Voelkl J, Lang F: Down-regulation of renal klotho expression by Shiga toxin 2. Kidney Blood Press Res 2014;39:441-449.

19 Bohnert BN, Daniel C, Amann K, Voelkl J, Alesutan I, Lang F, Heyne N, Haring HU, Artunc F: Impact of phosphorus restriction and vitamin D-substitution on secondary hyperparathyroidism in a proteinuric mouse model. Kidney Blood Press Res 2015;40:153-165.

20 Bergwitz C, Juppner H: Regulation of phosphate homeostasis by PTH, vitamin D, and FGF23. Annu Rev Med 2010;61:91-104.

21 Chesher D, Oddy M, Darbar U, Sayal P, Casey A, Ryan A, Sechi A, Simister C, Waters A, Wedatilake Y, Lachmann RH, Murphy E: Outcome of adult patients with X-linked hypophosphatemia caused by PHEX gene mutations. J Inherit Metab Dis 2018;41:865-876.

-22 Carpenter TO, Imel EA, Holm IA, Jan de Beur SM, Insogna KL: A clinician's guide to X-linked hypophosphatemia. J Bone Miner Res 2011;26:1381-1388.

-23 Huang X, Jiang Y, Xia W: FGF23 and Phosphate Wasting Disorders. Bone Res 2013;1:120-132.

-24 Pavone V, Testa G, Gioitta Iachino S, Evola FR, Avondo S, Sessa G: Hypophosphatemic rickets: etiology, clinical features and treatment. Eur J Orthop Surg Traumatol 2015;25:221-226.

25 Fajol A, Honisch S, Zhang B, Schmidt S, Alkahtani S, Alarifi S, Lang F, Stournaras C, Foller M: Fibroblast growth factor (Fgf) 23 gene transcription depends on actin cytoskeleton reorganization. FEBS Lett 2016;590:705-715.

-26 Zhang B, Yan J, Umbach AT, Fakhri H, Fajol A, Schmidt S, Salker MS, Chen H, Alexander D, Spichtig D, Daryadel A, Wagner CA, Foller M, Lang F: NFkappaB-sensitive Orai1 expression in the regulation of FGF23 release. J Mol Med (Berl) 2016;94:557-566.

27 Voelkl J, Tuffaha R, Musculus K, Auer T, Zickler D, Sacherer M, Metzler B, Müller DN, Pieske B, Lang F, Alesutan I: SGK1 induces vascular smooth muscle cell calcification through NF-kB signaling. J Clin Invest 2018;128:3024-3040.

28 Leibrock CB, Alesutan I, Voelkl J, Pakladok T, Michael D, Schleicher E, Kamyabi-Moghaddam Z, QuintanillaMartinez L, Kuro-o M, Lang F: NH4Cl Treatment Prevents Tissue Calcification in Klotho Deficiency. J Am Soc Nephrol 2015;26:2423-2433.

29 Lang F, Munzer P, Gawaz M, Borst O: Regulation of STIM1/Orai1-dependent Ca2+ signalling in platelets. Thromb Haemost 2013;110:925-930.

-30 Zhang B, Umbach AT, Chen H, Yan J, Fakhri H, Fajol A, Salker MS, Spichtig D, Daryadel A, Wagner CA, Foller M, Lang F: Up-regulation of FGF23 release by aldosterone. Biochem Biophys Res Commun 2016;470:384390.

31 Pathare G, Foller M, Michael D, Walker B, Hierlmeier M, Mannheim JG, Pichler BJ, Lang F: Enhanced FGF23 Serum Concentrations and Phosphaturia in Gene Targeted Mice Expressing WNK-Resistant Spak. Kidney Blood Press Res 2012;36:355-364.

-32 Pathare G, Foller M, Daryadel A, Mutig K, Bogatikov E, Fajol A, Almilaji A, Michael D, Stange G, Voelkl J, Wagner CA, Bachmann S, Lang F: OSR1-Sensitive Renal Tubular Phosphate Reabsorption. Kidney Blood Press Res 2012;36:149-161.

33 Umbach AT, El-Attar O, Luo D, Fakhri H, Bissinger R, Lang F: Impact of Annexin A 7 Deficiency on FGF23 Plasma Concentrations. Kidney Blood Press Res 2016;41:828-836. 


\section{Kidney \\ Blood Pressure Research}

-34 Zhang B, Yan J, Schmidt S, Salker MS, Alexander D, Foller M, Lang F: Lithium-Sensitive Store-Operated Ca2+ Entry in the Regulation of FGF23 Release. Neurosignals 2015;23:34-48.

35 Fakhri H, Pathare G, Fajol A, Zhang B, Bock T, Kandolf R, Schleicher E, Biber J, Foller M, Lang UE, Lang F: Regulation of mineral metabolism by lithium. Pflugers Arch 2014;466:467-475.

-36 Fakhri H, Ricken R, Adli M, Fajol A, Walter M, Foller M, Berlin Research Network of D, Lang F, Lang UE, Lange C: Impact of lithium treatment on FGF-23 serum concentrations in depressive patients. J Clin Psychopharmacol 2014;34:745-747.

-37 Lang F, Eylenstein A, Shumilina E: Regulation of Orai1/STIM1 by the kinases SGK1 and AMPK. Cell Calcium 2012;52:347-354.

-38 Nurbaeva MK, Schmid E, Szteyn K, Yang W, Viollet B, Shumilina E, Lang F: Enhanced Ca(2)(+) entry and $\mathrm{Na}+/ \mathrm{Ca}(2)(+)$ exchanger activity in dendritic cells from AMP-activated protein kinase-deficient mice. FASEB J 2012;26:3049-3058.

-39 Glosse P, Feger M, Mutig K, Chen H, Hirche F, Hasan AA, Gaballa MMS, Hocher B, Lang F, Foller M: AMPactivated kinase is a regulator of fibroblast growth factor 23 production. Kidney Int 2018;94:491-501.

-40 Yokoyama K: [Phosphate metabolism and iron deficiency]. Clin Calcium 2016;26:241-249.

41 Feger M, Fajol A, Lebedeva A, Meissner A, Michael D, Voelkl J, Alesutan I, Schleicher E, Reichetzeder C, Hocher B, Qadri SM, Lang F: Effect of carbon monoxide donor CORM-2 on vitamin D3 metabolism. Kidney Blood Press Res 2013;37:496-505.

42 Leifheit-Nestler M, Richter B, Basaran M, Nespor J, Vogt I, Alesutan I, Voelkl J, Lang F, Heineke J, Krick S, Haffner D: Impact of Altered Mineral Metabolism on Pathological Cardiac Remodeling in Elevated Fibroblast Growth Factor 23. Front Endocrinol (Lausanne) 2018;9:333.

43 Lin Z, Li W: The Roles of Vitamin D and Its Analogs in Inflammatory Diseases. Curr Top Med Chem 2016;16:1242-1261.

-44 Fan P, He L, Hu N, Luo J, Zhang J, Mo LF, Wang YH, Pu D, Lv XH, Hao ZM, Ding CH, Xue WJ, Li Y: Effect of 1,25-(OH)2D3 on Proliferation of Fibroblast-Like Synoviocytes and Expressions of Pro-Inflammatory Cytokines through Regulating MicroRNA-22 in a Rat Model of Rheumatoid Arthritis. Cell Physiol Biochem 2017;42:145-155.

45 Guillot X, Semerano L, Saidenberg-Kermanac'h N, Falgarone G, Boissier MC: Vitamin D and inflammation. Joint Bone Spine 2010;77:552-557.

46 He XJ, Ding Y, Xiang W, Dang XQ: Roles of 1,25(OH)2D3 and Vitamin D Receptor in the Pathogenesis of Rheumatoid Arthritis and Systemic Lupus Erythematosus by Regulating the Activation of CD4+ T Cells and the PKCdelta/ERK Signaling Pathway. Cell Physiol Biochem 2016;40:743-756.

47 David V, Martin A, Isakova T, Spaulding C, Qi L, Ramirez V, Zumbrennen-Bullough KB, Sun CC, Lin HY, Babitt JL, Wolf M: Inflammation and functional iron deficiency regulate fibroblast growth factor 23 production. Kidney Int 2016;89:135-146. 